\title{
Medverkande författare
}

MATS DELAND är docent i historia och forskare vid Hugo Valentincentrum vid Uppsala universitet. Deland har varit redaktör för antologierna Brunt! Nationalistisk och nazistisk mobilisering $i$ vår närmaste omvärld under efterkrigstiden (2007, tillsammans med Charles Westin) och In the Tracks of Breivik. Far Right Networks in Northern and Eastern Europe (20I4, tillsammans med Michael Minkenberg och Christin Mays).

PAUL FUEHRER är universitetslektor i sociologi vid Södertörns högskola. Fuehrers forskningsintressen är socialvetenskapliga metoder - i synnerhet kvantitativa metoder, konsumtionssociologi, tidssociologi samt miljösociologi. Han disputerade 2010 på avhandlingen $O m$ tidens värde. En sociologisk studie av senmodernitetens temporala livsvärldar, och har bland annat varit redaktör (tillsammans med Patrik Aspers och Árni Sverrisson) för antologin Bild och samhälle. Visuell analys som vetenskaplig metod (2004).

FREDRIK HERTZBERG är lektor vid Institutionen för pedagogik och didaktik vid Stockholms universitet. Hertzbergs forskningsområde är övergången mellan skola och arbetsliv för ungdomar med utländsk bakgrund, och han studerar såväl ungdomarnas egna strategier och förhållningssätt, den utbildningspolitik som hanterar deras övergångar, samt bemötandet från professionella, institutionella aktörer - huvudsakligen med fokus på inkluderings- och exkluderingsprocesser. Bland nyare publikationer kan nämnas "Double Gestures of Inclusion and Exclusion" i International Journal of Qualitative Studies in Education (2015) 
samt "Vägledning, inkludering och exkludering" i Anders Lovén (red.) Karriärvägledning. En forskningsöversikt (2015).

TINE HUTZEL har en masterexamen i filosofi, litteraturvetenskap och historia vid Universität zu Köln. Hon är redaktör (tillsammans med Daniel Köhler) för Journal for Deradicalization och fristående journalist med inriktning på högerextremism.

THOMAS HVITFELDT är fil.kand i sociologi med en mångårig erfarenhet som utredare från både myndigheter och civilsamhällesorganisationer.

DANIEL KÖHLER, med en masterexamen i freds- och konfliktkunskap från Universität Hamburg, är grundare och chef för German Institute on Radicalization and De-radicalization Studies (GIRDS). Han har tidigare varit med och grundat Institute for the Study of Radical Movements (ISRM) i Berlin, där han var forskningsledare fram till 20I4, och den första sakkunniggranskade open access-tidskriften om avradikalisering: Journal for Deradicalization, där han är redaktör tillsammans med Tine Hutzel. Köhler är knuten som expert till extremismprogrammet vid George Washington University's Center for Cyber and Homeland Security.

MARKUS LUNDSTRÖM forskar om motstånd och sociala rörelser vid Ekonomisk-historiska institutionen vid Stockholms universitet. I hans avhandlingsprojekt undersöks hur motstånd skapas över tid, och hur "tid" i sin tur skapas av den brasilianska jordockupationsrörelsen Movimento dos Trabalhadores Rurais Sem Terra (MST). Markus har även bedrivit publicerad forskning om livsmedelssektorns globalisering och ingår för närvarande i ett forskningsprojekt om de så kallade Husbyhändelserna.

TOMAS LUNDSTRÖM studerar masterprogrammet i religion i fred och konflikt vid Uppsala universitet, med särskilt intresse för religionshistoria och sociala aspekter av religiöst färgade konflikter. Tomas är även frilansskribent och redaktör till antologierna Att hoppas på ett annat system (tillsammans med Anton Lundqvist, 2013) och Kroppen (2012). 
CAS MUdDE är docent i statsvetenskap vid School of Public and International Affairs vid University of Georgia. Han är en av grundarna av European Consortium for Political Researchs ständiga grupp för studiet av extremism och demokrati och forskar på hur liberala demokratier kan skydda sig själva mot politiska utmaningar utan att undergräva sina demokratiska grundvalar. Han har bland annat skrivit den inflytelserika boken Populist Radical Right Parties in Europe (2007).

ADRIENNE SÖRBOM är lektor och docent i sociologi vid Södertörns högskola samt forskare vid Stockholms centrum för forskning om offentlig sektor (Score) vid Stockholms universitet. Sörboms forskningsintressen rör politik och organisation i ett brett perspektiv. Under senare år har hon bland annat studerat radikala vänsterrörelser i Sverige, företagsledd politik, tankesmedjor och politisk globalisering. Under 2012 kom hon ut med boken Politikens gränser. Globalisering, socialdemokrati och banden till nationen.

BENJAMIN R. TEITELBAUM är lektor och prefekt i nordiska studier vid University of Colorado, Boulder. Hans etnografiskt inriktade forskning fokuserar på musik och kulturyttringar i radikalnationalistiska rörelser. Hans avhandling från 2013, "Come Hear Our Merry Song". Shifts in the Sound of Contemporary Swedish Radical Nationalism, har belönats med flera utmärkelser och under 2016 kommer han ut med boken Lions of the North. Sounds of the New Nordic Radical Nationalism.

MAGNUS WENNERHAG är lektor i sociologi vid Södertörns högskola samt forskare i sociologi vid Göteborgs universitet. Han disputerade 2008 på avhandlingen Global rörelse. Den globala rättviserörelsen och modernitetens omvandlingar. Under senare år har han bland annat forskat om radikala vänsterrörelser i Sverige, Danmark, Tyskland, Polen och Ryssland, medborgarnas deltagande i demonstrationer (med fokus på förstamajdemonstrationer och prideparader) samt det svenska civilsamhällets europeisering. 
Trots att samhällsvetenskapen och skönlitteraturen har fascinationen inför samhället och det sociala samspelet gemensamt, så har skönlitteraturen märkligt nog inte någon naturlig plats i samhällsvetarens verktygslåda. Det vill vi råda bot på med Sociologi genom litteratur. Skönlitteraturens möjligheter och samhällsvetenskapens begränsningar, en antologi där 31 sociologer i korta kapitel låter skönlitterära verk ge näring åt den sociologiska fantasin. Boken tjänar både som en reflektion över samhällsvetenskapens egenart och som en inbjudan till samhällsvetare att använda skönlitteraturen som ett fönster mot den sociala verkligheten.

Arkiv förlag, 336 sidor
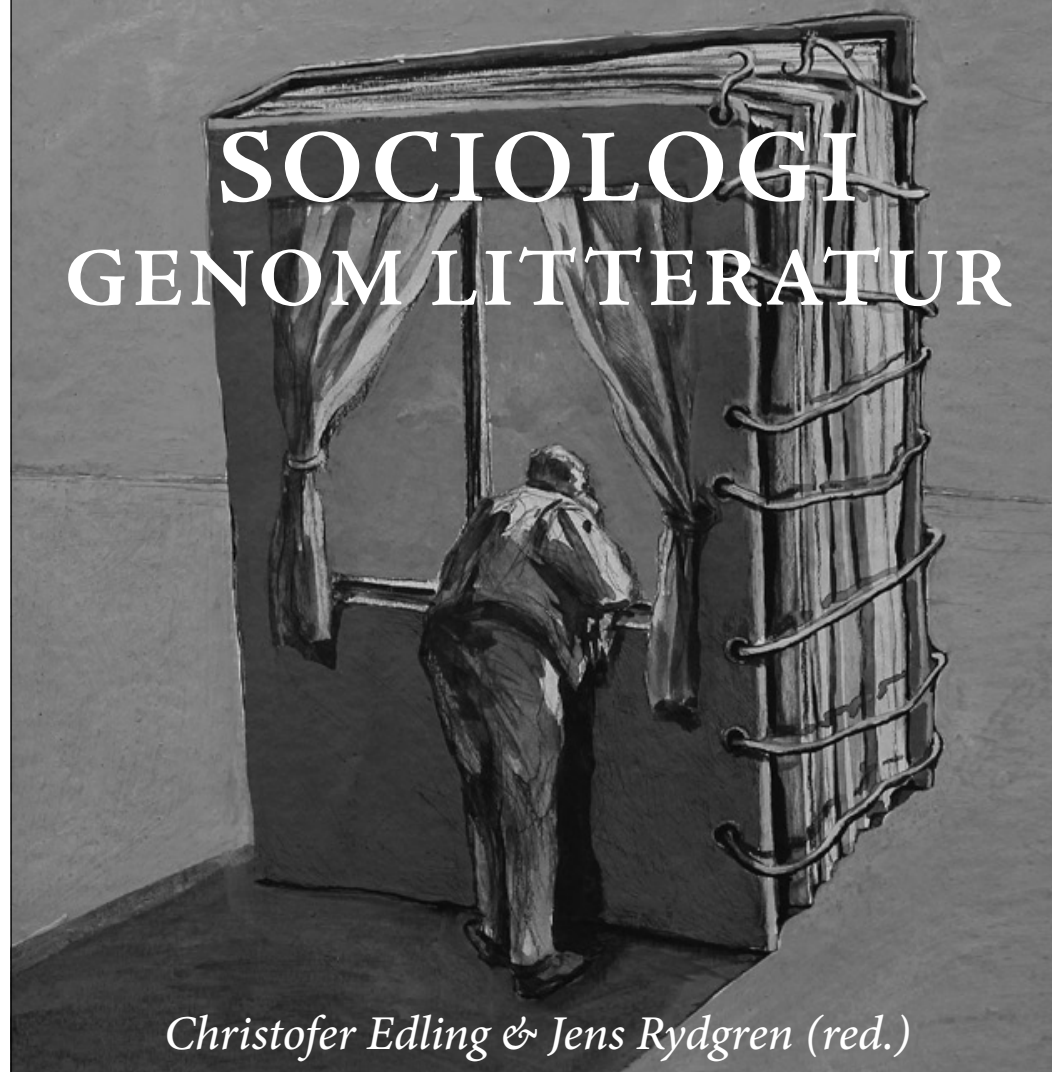

»Läs mer om boken på www.arkiv.nu« 